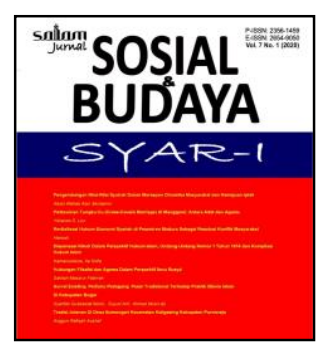

P-ISSN: 2356-1459. E-ISSN: 2654-9050

Vol. 8 No. 1 (2021), pp. 159-172

DOI: 10.15408/sjsbs.v8i1.19395

http://journal.uinjkt.ac.id/index.php/salam/index

\title{
Hak Masyarakat Hukum Adat Dalam Pelaksanaan Pengadaan Tanah Ulayat Bagi Pembangunan Untuk Kepentingan Umum*
}

\author{
Miranda Nissa, ${ }^{1}$ Atik Winanti ${ }^{2}$ \\ Universitas Pembangunan Nasional Veteran Jakarta
}

do

Abstract

$\underline{10.15408 / s j s b s . v 8 i 1.19395}$

Land is a natural wealth that is very important for humans and has an important function in development. In carrying out activities carried out by the government, namely land acquisition for the public interest, which has the aim of building public facilities for the benefit of the community. In carrying out land acquisition, ulayat land is often the target for alleged land acquisition. However, using ulayat land for land acquisition often creates problems. The purpose of this paper is to determine the control of indigenous peoples' rights in land acquisition and to determine the role of the state in providing compensation for land acquisition for development in the public interest. The research method used is juridical normative using a statutory approach and a conceptual approach. The result of this research is that the rights of customary law communities have been regulated constitutionally by the State, and the role of indigenous peoples is regulated in Law no. 71/2012. However, the fact is that during the land acquisition process, customary law communities are often not involved, the government should provide legal certainty and protection to the customary law community so that these problems do not harm the customary law community.

Keyword: Land Procurement, Customary Law Communities, Customary Land.

\begin{abstract}
Abstrak
Tanah merupakan kekayaan alam yang sangat penting bagi manusia dan memiliki fungsi yang penting dalam pembangunan. Dalam melakukan kegiatan yang dilakukan oleh pemerintah yaitu pengadaan tanah bagi kepentingan umum, yang mana memiliki tujuan untuk membangun fasilitas umum agar bermanfaat bagi masyarakat. Dalam melakukan pengadaan tanah, seringkali tanah ulayat dijadikan sasaran untuk digunakan pengadaan tanah. Namun, dalam menggunakan tanah ulayat untuk pengadaan tanah tersebut seringkali menimbulkan masalah. Tujuan dari penulisan ini untuk mengetahui pengaturan mengenai hak-hak masyarakat adat dalam pengadaan tanah dan untuk mengetahui peran negara dalam pemberian ganti kerugian pada pengadaan tanah bagi pembangunan untuk kepentingan umum. Metode penelitian yang digunakan adalah yuridis normatif dengan menggunakan pendekatan perundangundangan dan pendekatan konseptual. Hasil dari penelitian ini adalah bahwa hak masyarakat hukum adat telah diatur secara konstitusional oleh Negara, serta peran masyarakat hukum adat diatur di dalam Undang-Undang No. 71/2012. Namun pada faktanya saat proses pengadaan tanah, masyarakat hukum adat seringkali tidak dilibatkan, seharusnya pemerintah dalam pengadaan tanah memberikan kepastian serta perlindungan hukum kepada masyarakat hukum adat agar permasalahan-permasalahan tersebut tidak merugikan masyarakat hukum adat.
\end{abstract}

Kata Kunci: Pengadaan Tanah, Masyarakat adat, Tanah Ulayat.

${ }^{*}$ Received: January 16, 2021, Revision: January 20, 2021, Published: February 08, 2021.

${ }^{1}$ Miranda Nissa adalah Mahasiswa Sarjana Hukum, Universitas Pembangunan Nasional Veteran Jakarta. E-mail: mirandanissa01@gmai.com

${ }^{2}$ Atik Winanti adalah Dosen Fakultas Hukum di Universitas Pembangunan Nasional Veteran Jakarta. 


\section{A. PENDAHULUAN}

Tanah memiliki berbagai sumber daya alam yang mana merupakan sumber penghidupan penting dalam memenuhi kebutuhan hidup manusia. Tanah dan manusia memiliki hubungan yang sangat erat, setiap aktivitas manusia membutuhkan tanah sebagai penunjang kegiatan kehidupan manusia, sehingga manusia tidak dapat dipisahkan dari tanah. ${ }^{3}$ Selain itu, tanah merupakan modal utama bagi kelancaran pembangunan. ${ }^{4}$ Menurut Arie Sukanthi Hutagalung "Tanah merupakan aset Negara yang

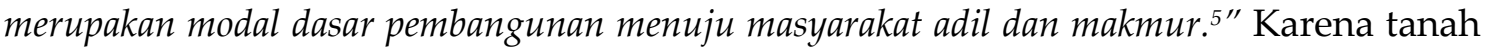
merupakan modal terpenting dalam pembangunan ekonomi bagi kehidupan masyarakat sehingga memungkinkan adanya kompleksitas permasalahan mengenai tanah dengan peningkatan kebutuhan ekonomis terhadap tanah tersebut. Dalam hal ini, penggunaan tanah wajib dimanfaatkan untuk kesejahteraan serta kemakmuran rakyat, hal ini pun tetap harus menjaga kelestarianya. ${ }^{6}$ Dengan perkembangan jumlah penduduk kebutuhan akan tanah untuk tempat tinggal juga semakin naik, karena tempat tinggal sangatlah penting untuk keberlangsungan kehidupannya. ${ }^{7}$

Permintaan pemerintah akan lahan di pedesaan maupun perkotaan sangat urgen dan mendesak. Contohnya, dalam pembuatan dan pelebaran jalan, pemukiman baru di pinggiran kota, pembangunan proyek bandara, dan infrastruktur publik lainya seperti sekolah, terminal, rumah sakit, pasar, dan lain-lain. ${ }^{8}$ Dengan hal ini, cara yang dapat dilakukan untuk memenuh kebutuhan infrastruktur tersebut, maka diadakan lah pengadaan tanah. ${ }^{9}$ Dalam melaksanakan pembangunan pengadaan tanah bagi kepentingan umum pemerintah memiliki kewajiban menyediakan tanah yang digunakan untuk pembangunan, tanah pun memiliki jenis status yang berbeda-beda yaitu: a). Tanah Negara, tanah ini merupakan milik negara sehingga dikuasai dan diakui oleh negara; b). Tanah Hak, merupakan tanah milik seseorang atau badan hukum; c). Tanah Ulayat, merupakan tanah yang dimiliki atau dikuasai bersama oleh masyarakat hukum adat setempat. ${ }^{10}$

Pengadaan tanah merupakan kegiatan yang dilakukan oleh pemerintah, dalam hal ini pemerintah memiliki tugas serta tanggung jawab untuk memajukan dan

${ }^{3}$ Happy Truzna Wijaya, 2020, Tinjauan Hukum Pelepasan Tanah Ulayat, Mimbar Keadilan Vol. 13 Nomor 1, hlm. 108.

${ }^{4}$ Retno Mumpuni, dkk, 2017, Peran Serta Ondofolo Dalam Ganti Rugi Tanah Untuk Kepentingan Umum Yang Berkeadilan Jurnal Ilmiah Pendidikan Pancasila dan Kewarganegaraan, Vol. 2 No. 1, hlm.65.

5 Arie Sukanthi Hutagulung, 2007, Kewenangan Pemerintah di Bidang Pertanahan, PT. Raja Grafindo: Jakarta, hlm.67.

${ }^{6}$ Ahmad Fauzie Ridwan, 1982, Hukum Tanah Adat, Dewarucci press: Jakarta, hlm.24.

7 Rahmat Ramadhani, 2019, Eksistensi Hak Komunal Masyarakat Hukum Adat Dalam Pengadaan Tanah Untuk Kepentingan Umum, Jurnal Penelitian Hukum De Jure Vol. 19 No.1, hlm. 98.

${ }^{8}$ Widyarini Indriasti Wardani, 2013, Pengadaan Tanah Bagi Pembangunan Untuk Kepentingan Umum (Telaah Terhadap Undang-Undang Nomor 2 Tahun 2012 Tentang Pengadaan Tanah Bagi Pembangunan Untuk Kepentingan Umum), Jurnal Hukum dan Dinamika Masyarakat Vo. 10 No.2, hlm.209

9 Aartje Tehupeiory, 2017, Problematika Pertanahan dan Strategi Penyelesaian Konsinyasi Pengadaan Tanah Untuk Kepentingan Umum, Prosiding Seminar Nasional: Problematika Pertanahan dan Strategi Penyelesaiannya, hlm.3.

${ }^{10}$ Aartje Tehupeiory, loc.cit. 
menyejahterakan masyarakatnya. ${ }^{11}$ Untuk menyejahterakan masyarakatnya, hal ini pun diatur dalam Pasal 33 ayat (3) Undang-Undang Dasar Negara Republik Indonesia 1945 menyebutkan bahwa: "bumi, air dan kekayaan alam yang terkandung di dalamnya itu harus dikuasai oleh negara dan dipergunakan untuk sebesar-besarnya kemakmuran rakyat". ${ }^{12}$

Dengan hal ini, pasal tersebut sangatlah jelas mengandung amanat konstitusi yaitu dalam memanfaatkan dan menggunakan tanah wajib untuk memberikan kesejahteraan kepada seluruh rakyat Indonesia dikarenakan setiap hak atas tanah tersebut harus lah memiliki kepastian mengenai subyek, obyek dan pelaksanaan kewenangan haknya. ${ }^{13}$

Dalam melakukan pengadaan tersebut, tanah ulayat sering sekali dijadikan pengadaan tanah untuk kepentingan umum. Tanah ulayat adalah tanah milik bersama masyarakat hukum adat sekitar, masyarakat adat pun memiliki hak atas penguasaan tanah tersebut yang dapat disebut hak ulayat. Atas hak ulayat yang dimiliki oleh masyarakat hukum adat pun memiliki kewenangan serta kewajiban yang berkaitan dengan tanah disekitarnya. ${ }^{14}$ Namun dalam melakukan pengadaan tanah sering sekali tidak berjalan dengan lancar yang mana salah satunya disebabkan oleh masyarakat hukum adat yang enggan melepaskan, karna adanya tidak kesesuaian mengenai pemberian ganti rugi dan dinilai tidak layak sehingga tidak menjamin kehidupan yang lebih baik. ${ }^{15} \mathrm{Hal}$ ini pun banyak menimbulkan permasalahan dan ketidakpastian serta ketidakadilan pada masyarakat hukum adat.

Mengenai ganti rugi, hal ini diatur dalam Pasal 1 angka 2 Peraturan Presiden Nomor 71 Tahun 2012 yang menyatakan bahwa "Pengadaan tanah adalah kegiatan menyediakan tanah dengan cara ganti kerugian yang yang layak dan adil kepada pihak yang berhak."16 Sedangkan dalam Pasal 1 angka (10) Undang-Undang Nomor 2 Tahun 2012 tentang Pengadaan Tanah Bagi Kepentingan Umum menyebutkan bahwa "Ganti kerugian adalah penggantian yang layak dan adil kepada pihak yang berhak dalam proses pengadaan tanah. ${ }^{\prime 17}$

Sering sekali terjadinya permasalahan mengenai pengadaan tanah ulayat, contoh terjadi pada suku Wally di Papua yang mana terjadinya konflik karena suku Wally belum menerima ganti rugi hak ulayat tanah pembangunan stadion Papua Bangkit sejak tahun 2017 lalu. Padahal pembangunan stadion terbesar kedua di Indonesia tinggal beberapa persen lagi selesai dikerjakan, namun sampai saat ini

11 Yanto Sufriadi, 2011, Penyebab Sengketa Pengadaan Tanah Untuk Kepentingan Umum (Studi Kasus Sengketa Pengadaan Tanah Untuk Kepentingan Umum di Bengkulu), Jurnal Hukum Vol. 18 No. 1, hlm. 43.

12 Pasal 33 ayat (3) Undang-Undang Dasar Negara Republik Indonesia 1945

${ }^{13}$ Rusmadi Murad, 2007, Menyingkap Tabir Masalah Pertanahan, Mandar Maju, Bandung, h.75.

14 Boedi Harsono, 1999, Hukum Agraria Indonesia Sejarah Pembentukan Undang-Undang Pokok Agraria Isi dan Pelaksanaanya, Jilid 1, Djamatan, hlm 235.

${ }^{15}$ Hasan Basri, 2013, Keadilan dan Kepastian Hukum Bagi Pemegang Hak Atas Tanah Dalam Pengadaan Tanah Untuk Kepentingan Umum, Jurnal IUS, Vol. 1 No.1, hlm. 78.

${ }_{16}$ Pasal 1 angka 2 Peraturan Presiden Nomor 71 Tahun 2012

17 Pasal 1 angka (10) Undang-Undang Nomor 2 Tahun 2012 tentang Pengadaan Tanah Bagi Kepentingan Umum 
pengadaan tanah tersebut tidak ada kepastian mengenai ganti rugi. ${ }^{18}$ Permasalahan pengadaan tanah lainya juga sering terjadi dikarenakan hak masyarakat adat diabaikan dalam pengganti rugi tanah tidak layak, sehingga tidak memperoleh tanah pengganti yang sama nilai ekonominya dengan tanah semula. Kemudian, mengenai musyawarah sering sekali tidak seimbang dalam penetapan ganti rugi yang mana belum tercapai kata sepakat. Padahal, tanah sangat diperlukan untuk proyek pembangunan maka penghitungan ganti rugi berdasarkan NJOP jauh dari rasa keadilan dan tidak ada penghormatan kepada hak masyarakat dan lain sebagainya. ${ }^{19}$ Sehingga, dalam pengadaan tanah ulayat ini banyak menimbulkan permasalahan yang mana hak masyarakat adat tidak terpenuhi serta dalam memberikan ganti rugi tidak layak dan adil seperti yang telah di atur dalam Undang-Undang.

Penelitian terhadap hak masyarakat hukum adat serta pengaturan negara dalam memberikan ganti kerugian atas pengadaan tanah bagi kepentingan umum, diharapkan dapat memberikan kepastian hukum mengenai hak masyarakat adat serta dalam memberikan ganti rugi. Berdasarkan latar belakang tersebut, penelitian ini mengambil judul mengenai "Hak Masyarakat Hukum Adat Atas Penggunaan Tanah Ulayat Dalam Pengadaan Tanah Bagi Kepentingan Umum." Maka berdasarkan latar belakang yang telah penulis uraikan di atas, makan ditarik suatu permasalahan, yaitu: Bagaimana hak masyarakat hukum adat terkait tanah ulayat pada pelaksanaan pengadaan tanah bagi kepentingan umum? Bagaimana peran Negara dalam memberikan perlindungan bagi masyarakat Hukum Adat terkait ganti kerugian?

\section{B. METODE PENELITIAN}

Jenis Penelitian yang digunakan oleh penulis yaitu menggunakan metode penelitian hukum yuridis normatif. Penelitian hukum yuridis normatif merupakan penelitian yang menggunakan sumber kepustakaan atau bahan sekunder yang dikumpulkan untuk diteliti dan dianalisa. ${ }^{20}$ Jenis pendekatan yang digunakan dalam penelitian ini adalah melalui Pendekatan Perundang-Perundang-undangan (Statue Approach) yang mana dalam melakukan penulisan dilakukan dengan menelaah beberapa undang-undang yang terkait dengan penulisan ini, lalu menggunakan Pendekatan Konseptual (Copceptual Approach) yang mana dalam penelitian ini berangkat dari teori-teori ilmu dari ilmu hukum yang memperjelas ide-ide mengenai pengertian, konsep atau asas yang berkaitan dengan permasalahan dalam penelitian ini.

\section{HASIL TEMUAN DAN PEMBAHASAN}

1. Hak Masyarakat Adat Terkait Tanah Ulayat Pada Pelaksanaan Pengadaan Tanah Bagi Pembangunan Untuk Kepentingan Umum.

18 Yewen, 2019, Ratusan Masyarakat Adat Suku Wally Tuntut Ganti Rugi Hak Ulayat, https://www.jpnn.com/news/ratusan-masyarakat-adat-suku, di akses pada 21 Oktober.

${ }^{19}$ Aartje Tehupeiory

${ }^{20}$ Ronny Hanitijo Soemitro, 1985, Metode Penelitian Hukum, Ghalia Indonesia: Jakarta, hlm. 93 
Tanah sangat dibutuhkan dalam melakukan pengadaan tanah bagi kepentingan umum, namun luas tanah di Indonesia sangatlah terbatas tetapi kegiatan pembangunan terus bertambah dan meningkat. ${ }^{21}$ Hal ini menyebabkan sulitnya menjalankan pembangunan di atas tanah milik Negara, dikarenakan keterbatasan tanah yang dimiliki oleh negara karena sebagian tanah negara telah dikuasai atau telah dimiliki masyarakat. Sedangkan, pembangunan infrastruktur untuk kepentingan umum harus tetap berjalan namun adanya keterbatasan tanah maka upaya yang dapat dilakukan oleh pemerintah untuk mendapatkan tanah-tanah tersebut, yaitu dengan melakukan pembebasan hak atau pencabutan hak atas tanah tersebut. ${ }^{22}$ Kegiatan pembebasan tanah atau pencabutan hak tersebut yang dilakukan oleh pemerintah dapat disebut dengan pengadaan tanah bagi kepentingan umum. ${ }^{23}$

Tanah memiliki kedudukan yang penting dalam kehidupan manusia terutama bagi masyarakat Hukum Adat. Hubungan tanah dengan masyarakat adat terjadi karena berbagai kepentingan, tanah tersebut dijadikan pemukiman untuk keperluan mencari mata pencarian, tempat berkumpul dan tempat ibadah. Masyarakat dengan tanah yang didudukinya memiliki hubungan yang erat. ${ }^{24}$ Hubungan antara masyarakat adat dengan tanah sangat erat dan bersifat menguasai, memanfaatkan tanah tersebut. Hak Masyarakat adat hukum adat disebut dengan hak pertuanan atau ulayat. Menurut G. Kartasapoetra dkk, bahwa pengertian tanah ulayat ialah:

"Hak ulayat merupakan hak tertinggi atas tanah yang dimiliki oleh sesuatu persekutuan hukum (desa, suku) untuk menjamin ketertiban pemanfaatan/pendayagunaan tanah. Hak ulayat adalah hak yang dimiliki oleh suatu persekutuan hukum (desa, suku), dimana para warga masyarakat (persekutuan hukum) tersebut mempunyai hak untuk menguasai tanah, yang pelaksanaannya diatur oleh ketua persekutuan (kepala suku/kepala desa yang bersangkutan."

Dalam hal ini, Boedi Harsono menyatakan:

"Hak ulayat merupakan serangkaian wewenang dan kewajiban suatu masyarakat hukum adat, yang berhubungan dengan tanah yang terletak dalam lingkungan wilayahnya, yang telah diuraikan di atas merupakan pendukung utama penghidupan dan kehidupan masyarakat yang bersangkutan sepanjang masa. Kewenangan dan kewajiban tersebut masuk dalam bidang hukum perdata dan ada yang masuk dalam bidang hukum publik. Kewenangan dan kewajiban dalam bidang hukum perdata berhubungan dengan hak bersama kepunyaan atas tanah tersebut. Sedangkan dalam hukum publik, berupa tugas kewenangan untuk mengelola, mengatur dan memimpin peruntukan, penguasaan, penggunaan, dan pemeliharaannya ada pada Kepala Adat/Ketua Adat." 25

\footnotetext{
${ }^{21}$ Hardianto Djanggih, 2017, Aspek Hukum Pengadaan Tanah bagi Pelaksanaan Pembangunan untuk Kepentingan Umum, Jurnal Hukum Pandecta Vol. 12 No. 2, hlm.167.

22 Chaizi Nasucha, 1994, Politik Ekonomi Pertanahan dan Struktur Perpajakan atas Tanah, Jakarta: Kesaint Blanc, hlm. 74.

${ }^{23}$ Rachmi Syarfina, 2019, Pengaruh Hukum Adat Dalam Proses Peralihan Hak Tanah Ulayat Pada Pembangunan Perluasan Bandara di Jayapura, Otentik's: Jurnal Hukum Kenotariatan Vol. 1, No,1, hlm.50.

${ }^{24}$ Marulak Togatorop, 2020, Perlindungan Hak Atas Tanah Masyarakat Hukum Adat Dalam Pengadaan Tanah Untuk Kepentingan Umum, Yogyakarta, hlm. 149.

${ }^{25}$ Ibid. hlm. 109.
} 
Keberadaan dan pengakuan mengenai hak-hak masyarakat hukum adat di Indonesia diatur di dalam Undang-Undang Dasar Negara Republik Indonesia 1945 dan peraturan perundang-undangan lainya. Bahwa dalam hal ini keberadaan dan hakhak masyarakat hukum adat telah diterima dalam kerangka hukum yang berlaku di Indonesia. Pengakuan dan keberadaan masyarakat hukum adat serta hak ulayatnya diatur dalam Pasal 18 B ayat (2) yang berbunyi

"Negara mengakui dan menghormati kesatuan-kesatuan masyarakat hukum adat beserta hak-hak tradisionalnya sepanjang masih hidup dan sesuai dengan perkembangan masyarakat hukum dan prinsip Negara Kesatuan Republik Indonesia, yang diatur dalam udang-undang." 26

Diatur juga dalam Pasal 28 I ayat (3) yang berbunyi: "Identitas budaya dan hak masyarakat tradisional dihormati selaras dengan perkembangan zaman dan peradaban."27

Pengakuan keberadaan serta hak-hak masyarakat hukum adat pada kenyataannya dituang dalam pasal tersebut seringkali masih tidak konsisten dan pengaturan mengenai masyarakat hukum adat serta hak ulayatnya sampai sekarang masih tidak jelas dan tidak tegas. Dalam hal ini, pengaturan mengenai keberadaan serta apa saja hak-hak yang dapat dinikmati oleh masyarakat hukum adat terutama dalam pelaksanaan pengadaan belum lah jelas dan tegas. ${ }^{28}$

Ketentuan masyarakat adat dalam pengadaan tanah pun diatur dalam Peraturan Presiden No. 71 Tahun 2012 Pasal 22 yang berbunyi:

“(1) Masyarakat hukum adat sebagaimana dimaksud dalam pasal 17 ayat (2) huruf e harus memenuhi syarat:

a. Terdapat sekelompok orang yang masih terikat oleh tatanan hukum adatnya sebagai warga bersama suatu persekutuan tertentu, yang mengakui dan menerapkan ketentuan persekutuan tersebut dalam kehidupan sehari-hari;

b. Terdapat tanah ulayat tertentu yang menjadi lingkungan hidup para warga persekutuan hukum adat tersebut dan tempatnya mengambil keperluan hidupnya sehari-hari; dan

c. Terdapat tatanan hukum adat mengenai pengurusan, penguasaan dan penggunaan tanah ulayat yang berlaku dan ditaati oleh para warga persekutuan hukum adat tersebut.

(2) Masyarakat hukum adat sebagaimana dimaksud pada ayat (1) keberadaannya diakui setelah dilaksanakannya penelitian dan diterapkan dengan peraturan daerah setempat." 29

Masyarakat adat memiliki peran dalam pengadaan tanah hal ini pun diatur di dalam UU Pengadaan Tanah, yang mana masyarakat terkena dampak serta yang wilayahnya termasuk lokasi pengadaan tanah dapat ikut serta berperan untuk

${ }^{26}$ Lihat pada Pasal 18 B ayat (2) Undang-Undang Negara Republik Indonesia 1945

${ }^{27}$ Lihat pada Pasal 28 I ayat (3) Undang-Undang Negara Republik Indonesia 1945

${ }^{28}$ Marulak Togatorop, Op.Cit, hlm 160.

${ }^{29}$ Lihat pada Pasal 22 Peraturan Presiden 71 Tahun 2012 
menentukan rencana pembangunan. Masyarakat hukum adat dilibatkan dalam proses bermusyawarah yang mana kegiatan saling mendengarkan pendapat dan keinginan agar tercapainya kata sepakat mengenai bentuk ganti kerugian antara pemilik hak atas tanah dan pihak yang memerlukan tanah. ${ }^{30}$ Hal ini pun masyarakat adat dapat bermusyawarah yang mana kegiatan saling mendengarkan pendapat dan keinginan mengenai bentuk kerugian agar terjadinya kesepakatan antara pemilik hak atas tanah dan pihak. Hak masyarakat adat lainnya dalam pengadaan tanah pun diatur dalam pasal 57, yang berbunyi: "a. Memberikan masukan secara lisan atau tertulis mengenai Pengadaan Tanah; dan b. Memberikan dukungan dalam penyelenggaraan Pengadaan Tanah."

Hal ini pun wajib untuk melibatkan masyarakat dalam kegiatan musyawarah, apabila tidak dilibatkan dalam proses maka akan terjadinya permasalahan mengenai hal ganti rugi dikarenakan masyarakat hukum adat tidak tahu mengenai informasi tersebut serta hal ini dilakukan agar mencegah adanya hambatan selama kegiatan pengadaan tanah. ${ }^{31}$ Namun dalam fakta lapangan, saat proses pengadaan tanah masyarakat hukum adat tidak dilibatkan, contoh konkret dalam pengadaan tanah pembangunan Jalan Trans Papua di Papua Barat bahwa masyarakat Adat marga MOMO selaku pemegang hak atas tanah ulayat tersebut, tanahnya diambil begitu saja tanpa adanya proses musyawarah mengenai ganti rugi dan pelepasan hak dengan masyarakat adat marga momo. Saat proses tersebut, bahwa masyarakat adat marga momo tidak pernah diberi informasi, diudang atau diajak berbicara mengenai sosialisasi maupun bentuk konsultasi publik mengenai tanah ulayatnya yang akan digunakan untuk pembangunan Jalan Trans Papua. ${ }^{32}$

Maka dalam hal ini perlu lah diperjelas mengenai hak-hak masyarakat adat dalam pengadaan tanah secara jelas. Dikarenakan pengaturan hak-hak tersebut, masih tidak bisa melindungi masyarakat adat. Hal ini pun tidak selaras dengan tujuan pengadaan tanah untuk kepentingan umum yaitu, untuk memberikan fasilitas umum yang mana memiliki tujuan agar dapat menyejahterakan serta meningkatkan kemakmuran bangsa, negara dan tetap menjamin kepentingan masyarakat. ${ }^{33}$ Menurut Utrech:

"Bahwa hukum merupakan suatu gabungan peraturan-peraturan baik mengenai perintah maupun larangan-larangan yang mengatur mengenai tata tertib yang berada di masyarakat dan masyarakat pun harus menaati peraturan tersebut. Karna tujuan hukum dibuat yaitu untuk melindungi kepentingan-kepentingan masyarakat dan untuk menciptakan ketertiban yang ada dimasyarakat, sehingga hukum harus

${ }^{30}$ Yanto Sufriadi, Op.Cit, hlm.53.

31 Hery Zakarsih, 2018, Pelaksanaan Peran Serta Masyarakat Pada Pengadaan Tanah Untuk Kepentingan Umum (Studi Kasus Pelebaran Jalan di Kota Praya, Kabupateen Lombok Tengah), Media Keadilan: Jurnal Ilmu Hukum Vol. 9 No. 2, hlm.147

${ }^{32}$ Charles Imbiri, Tak Dapat Ganti Rugi, Masyarakat Palang Jalan Trans Papua Manokwari Sorong, https://www.mcwnews.com/read/2019/02/23/3279/tak-dapat-ganti-rugi-masyarakat-palang-jalantrans-papua-manokwari-sorong.html, diakses pada 22 Januari 2021.

${ }^{33}$ Ibid. 
diperundangkan dan pengaturannya harus tegas dan jelas sehingga berhasil menciptakan kepastian hukum dan memberikan keadilan ke masyarakat." 34

Maka dari permasalahan pengadaan tanah ini yang dilakukan oleh Pemerintah masyarakat adat memerlukan adanya kepastian hukum yang mana pembangunan tersebut tidak merugikan masyarakat adat. Masyarakat menginginkan peraturan mengenai pengadaan tanah yang lebih jelas dan tegas yang dapat melindungi masyarakat adat. Pengadaan tanah tersebut haruslah menghormati pengakuan hak masyarakat hukum adat, dikarenakan masyarakat adat pun telah diakui secara konstitusi oleh Negara ${ }^{35}$

\section{Peran Negara Dalam Memberikan Perlindungan Bagi Masyarakat Hukum Adat Terkait Ganti Kerugian.}

Tanah sangatlah dibutuhkan oleh pemerintah dalam melakukan pembangunan untuk kepentingan umum, hal ini pun bertujuan untuk membangun fasilitas umum yang mana kegiatan ini disebut pengadaan tanah. ${ }^{36}$ Penyelenggaraan pengadaan tanah bagi pembangunan untuk kepentingan umum, dilaksanakan dengan beberapa asas yang diatur dalam UU No. 2/2012 Pasal 2:

"Pengadaan tanah untuk kepentingan umum dilaksanakan berdasarkan asas:

a. Asas kemanusiaan ialah Pengadaan Tanah harus memberikan pelindungan serta penghormatan terhadap hak asasi manusia, harkat, dan martabat setiap warga negara dan penduduk Indonesia secara proporsional

b. Asas keadilan ialah memberikan jaminan penggantian yang layak kepada Pihak yang Berhak dalam proses Pengadaan Tanah sehingga mendapatkan kesempatan untuk dapat melangsungkan kehidupan yang lebih baik.

c. Asas kemanfaatan ialah hasil Pengadaan Tanah mampu memberikan manfaat secara luas bagi kepentingan masyarakat, bangsa, dan negara.

d. Asas kepastian ialah memberikan kepastian hukum tersedianya tanah dalam. proses Pengadaan Tanah untuk pembangunan dan memberikan jaminan kepada Pihak yang Berhak untuk mendapatkan Ganti Kerugian yang layak.

e. Asas keterbukaan ialah bahwa Pengadaan Tanah untuk pembangunan dilaksanakan dengan memberikan akses kepada masyarakat untuk mendapatkan informasi yang berkaitan dengan Pengadaan Tanah.

f. Asas kesepakatan ialah bahwa proses Pengadaan Tanah dilakukan dengan musyawarah para pihak tanpa unsur paksaan untuk mendapatkan kesepakatan bersama.

${ }^{34}$ C.S.T Kansil, 1989, Pengantar Ilmu Hukum dan Tata Tertib Hukum Indonesia, Balai Pustaka: Jakarta, hlm. 38 .

${ }^{35}$ Denico Doly, 2011, Keududukan Tanah Ulayat dalam Perancangan Undang-Undang tentang Pengadaan Tanah Untuk Pembangunan Umum, Jurnal Kajian Vol. 16 No. 3, hlm. 460.

36 Swingly Sengkey, 2019, Problematika Dalam Pengadaan Tanah Untuk Kepentingan Umum Menurut Undang-Undang Nomor 2 Tahun 2012, Lex Privatium Vol. 7 No. 1, hlm.60. 
g. Asas keikutsertaan ialah dukungan dalam penyelenggaraan Pengadaan Tanah melalui partisipasi masyarakat, baik secara langsung maupun tidak langsung, sejak perencanaan sampai dengan kegiatan pembangunan.

h. Asas kesejahteraan ialah bahwa Pengadaan Tanah untuk pembangunan dapat memberikan nilai tambah bagi kelangsungan kehidupan Pihak yang Berhak dan masyarakat secara luas.

i. Asas keberlanjutan ialah kegiatan pembangunan dapat berlangsung secara terusmenerus, berkesinambungan, untuk mencapai tujuan yang diharapkan.

j. Asas keselarasan ialah bahwa Pengadaan Tanah untuk pembangunan dapat seimbang dan sejalan dengan kepentingan masyarakat dan negara." ${ }^{37}$

Sehingga, dalam melakukan pengadaan tanah yang direncanakan oleh pemerintah harus lah sesuai dengan asas yang telah diatur dalam Undang-Undang, agar tujuan dari pengadaan tanah tersebut dapat memberikan fasilitas yang baik dan dapat digunakan dengan baik oleh masyarakat sekitar. Dalam pengadaan tanah, Pemerintah/Pemerintah daerah memiliki wewenang dalam melakukan pengadaan tanah. Hal ini pun diatur di dalam UU Pengadaan Tanah pasal 6 yang berbunyi: "Pengadaan Tanah untuk Kepentingan Umum diselenggarakan oleh Pemerintah" 38 dan diatur lebih lanjut dalam Peraturan Presiden Nomor 71 Tahun 2012 Pasal 47 ayat (1) yang berbunyi:

“Gubernur dapat mendelegasikan kewenangan pelaksaan persiapan Pengadaan Tanah bagi pembangunan untuk Kepentingan Umum kepada bupati/Walikota berdasarkan pertimbangan efisiensi, kondisi grafis, sumber daya manusia dan pertimbangan lainya" 39

Penjelasan pasal tersebut, bahwa Pemerintah/Pemerintah daerah memiliki wewenang yaitu dapat melaksanakan atau menjalankan pengadaan tanah tersebut. Dalam menjalankan proses kegiatan pengadaan tanah yang telah diatur pasal di atas maka gubernur mempunyai kewenangan sebagai Pemerintah Daerah provinsi, serta dalam menjalankan pengadaan tanah gubernur dapat melakukannya kewenangannya sendiri atau dapat didelegasikan kepada Bupati/Walikota. ${ }^{40}$ Tugas gubernur dalam melaksanakan kegiatan pengadaan tanah diatur dalam UU No. 71/2012 Pasal 8 s/d Pasal 46.

Pengadaan tanah yang dijalankan oleh Pemerintah atau Pemerintah Daerah harus memberikan manfaat serta menyejahterakan masyarakat serta tetap memperhatikan dan memberikan ganti kerugian kepada pihak yang berhak. Upaya untuk mewujudkan pembangunan untuk kepentingan umum, hal ini pun diatur di Undang-Undang Pokok Agraria No. 5 Tahun 1960 Pasal 18 yang menyatakan:

${ }^{37}$ Lihat pada penjelasan Pasal 2 Undang-Undang Nomor 2 Tahun 2012 tentang Pengadaan Tanah Bagi Kepentingan Umum.

${ }^{38}$ Lihat pada Pasal 6 Undang-Undang Nomor 2 Tahun 2012 tentang Pengadaan Tanah Bagi Kepentingan Umum.

${ }^{39}$ Lihat pada Pasal 47 ayat (1) Peraturan Presiden 71 Tahun 2012

40 Dkristian, D., Suyatna, I.N. And Dahana, C.D., Kewenangan Pemerintah Daerah Dalam Pengadaan Tanah Bagi Pelaksanaan Pembangunan Untuk Kepentingan Umum, hlm.4. 
"Untuk kepentingan umum, termasuk kepentingan bangsa dan Negara serta kepentingan bersama dari rakyat, hak-hak atas tanah dapat dicabut, dengan memberi ganti kerugian yang layak dan menurut cara yang diatur dengan Undang-undang"

Pemberian Ganti rugi adalah hak mutlak yang di dapatkan oleh pemegang hak atas tanah karena telah melepaskan tanahnya sehingga bentuk ganti kerugian tersebut sebagai imbalan sebagai pengganti dari nilai tanah serta benda-benda yang berada di atasnya. Prinsip dalam pemberian ganti rugi ialah harus memberikan imbalan kepada pemegang hak atas tanah dengan imbalan yang layak sehingga pemegang hak atas tanah tidak mengalami kemunduran ekonomi. ${ }^{41}$

Pemberian ganti kerugian adalah suatu bentuk penghormatan atas hak tanah sebagai bagian dari hak asasi manusia di sektor ekonomi (property right). Ganti rugi memberikan perlindungan kepentingan para pemegang hak atas tanah yang dibebaskan, serta memberikan ganti kerugian kepada pemegang hak atas tanah merupakan bagian yang sangat penting dalam melaksanakan pengadaan tanah. ${ }^{42}$

Mengenai ganti rugi pun diatur di dalam UU No. 2/2012 Pasal 1 angka (10) yang menyatakan "Ganti kerugian adalah penggantian yang layak dan adil kepada pihak yang berhak dalam proses pengadaan tanah."43 dalam ganti rugi yang diberikan kepada pihak yang berhak bukan merupakan harga beli. Hal ini pun perlu ditekankan agar tidak terjadi suatu asumsi bawah masyarakat bersedia menerima ganti rugi tersebut merupakan bentuk jual beli. ${ }^{44}$ Bentuk nilai ganti kerugian yang diberikan kepada pemegang hak atas tanah diatur dialam UU No. 2/2012 Pasal 36 yang meliputi: "a. tanah; b. tanah pengganti; c. pemukiman kembali; $d$. kepemilikan saham; atau e. bentuk lain yang disetujui oleh kedua belah pihak." 45

Pengadaan tanah sering sekali menggunakan tanah ulayat dijadikan sasaran untuk melakukan pembangunan bagi kepentingan umum. Dalam memberikan ganti rugi kepada masyarakat hukum adat berbentuk tanah pengganti, pemukiman kembali, atau bentuk lain yang telah disetujui oleh masyarakat hukum adat yang mana tidak melanggar ketentuan perundang-undangan. Namun, pengadaan tanah yang dijalankan oleh Pemerintah atau Pemerintah Daerah banyak sekali memiliki permasalahan atau kendala-kendala. Permasalahan dalam pengadaan terjadi dikarenakan dalam proses musyawarah tidak tercapai kesepakatan mengenai harga ganti rugi antara masyarakat adat dengan Pemerintah, hal ini pun menyebabkan proses pengadaan tanah menjadi berlarut-larut. ${ }^{46}$

${ }^{41}$ Dwi Wulan Pujiriyani, 2014, Pengadaan Tanah dan Problem Pemukiman kembali: Skema Pemberdayaan Untuk Perlindungan Masyarakat Terdampak, Jurnal Bhumi No. 40 Tahun 13, hlm.639.

${ }^{42}$ Ibid.

${ }^{43}$ Lihat pada Pasal 1 angka (10) Undang-Undang Nomor 2 Tahun 2012 tentang Pengadaan Tanah Bagi Kepentingan Umum.

${ }^{44}$ Ika Karolina Octafionita Oroh, 2018, Ganti Rugi Pembebasan Tanah Menutur Undang-Undang Nomor 2 Tahun 2012 Tentang Pengadaan Tanah Bagi Pembangunan Untuk Kepentingan Umum, Jurnal Lex Privatum Vo. 6 No. 3, hlm. 134

${ }^{45}$ Lihat pada Pasal 36 Undang-Undang Nomor 2 Tahun 2012 tentang Pengadaan Tanah Bagi Kepentingan Umum.

${ }^{46}$ Denico Doly, Op.Cit, hlm. 455 
Masyarakat hukum adat sebenarnya tidak keberatan jika tanah miliknya diambil alih untung pembangunan yang dapat memberikan manfaat dan menyejahterakan masyarakat, namun dalam proses pengambil alihan tanah sering sekali dimanfaatkan oleh kelompok-kelompok yang mana untuk menguntungkan sendiri dengan berasalan untuk kepentingan umum. Hal ini pun membuat timbulnya keraguan masyarakat adat setiap adanya kegiatan pengadaan tanah bagi pembangunan untuk kepentingan umum. ${ }^{47}$

Dalam hal pengadaan tanah ini pun, masyarakat merasa tidak puas dan masyarakat pun tidak memiliki daya hak atas tanahnya yang terkena proyek pengadaan tanah tersebut. Permasalahan ganti rugi ini yang paling susah untuk ditangani oleh pemerintah, dalam upaya yang dilakukan oleh pemerintah yang mana memanfaatkan hak atas tanah masyarakat hukum adat menimbulkan kerugian kepada masyarakat hukum adat dikarenakan bentuk atau ganti rugi yang diberi oleh pemerintah kepada masyarakat hukum adat tidak sesuai dengan apa yang diinginkan masyarakat hukum adat, bahkan ganti kerugian tersebut malah merugikan. ${ }^{48}$ Menurut Setiono bahwa: "Perlindungan hukum merupakan suatu tindakan atau upaya yang bertujuan untuk melindungi masyarakat dari perbuatan yang sewenang-wenangnya oleh penguasa yang tidak sesuai dengan aturan hukum demi mewujudkan ketertiban dan ketenteraman" 49

Namun dalam melakukan pengadaan tanah, pemerintah sering sekali mengabaikan hak-hak masyarakat hukum adat serta mengabaikan penghormatan terhadap hak atas tanah masyarakat hukum adat dan tidak menerapkan asas yang telah di atur oleh Pasal 2 UU No. 2/2012. Hal tersebut pun jelas bahwa dalam melakukan pengadaan tanah untuk kepentingan umum belum memberikan perlindungan serta tidak mencerminkan bahwa adanya perlindungan hukum yang jelas kepada masyarakat hukum adat.

\section{KESIMPULAN}

Dalam melakukan pengadaan tanah, tanah memiliki kedudukan yang penting dalam kehidupan manusia terutama bagi masyarakat Hukum Adat. Hubungan tanah dengan masyarakat adat terjadi karena berbagai kepentingan, tanah tersebut dijadikan pemukiman untuk keperluan mencari mata pencarian, tempat berkumpul dan tempat ibadah. Kegiatan pengadaan tanah bagi kepentingan umum diselenggarakan oleh pemerintah, dalam hal ini Pemerintah/Pemerintah Daerah memiliki wewenang dalam melaksanakan pengadaan tanah tersebut. Tanah ulayat milik masyarakat adat seringkali dijadikan untuk pengadaan tanah, maka dengan adanya pengadaan tanah yang dilakukan di atas tanah ulayat ini tentunya masyarakat adat pasti terlibat dalam proses pengadaan tanah. Masyarakat hukum adat beserta hak-haknya diaku keberadaannya di Indonesia, hal ini pun diatur dalam UUD 1945 pada Pasal 18B ayat (2) dan Pasal 28 I ayat (3). Serta ketentuan masyarakat hukum adat dalam pengadaan

\footnotetext{
${ }^{47}$ Marulak Togatorop, Op.cit, hlm 156.

48 Retno Mumpuni, Op.Cit , hlm. 68.

49 Setiono, 2004, Rule Of Law (Supermasi Hukum), Surakarta, Magister Ilmu Hukum Program Pascasarjana Universitas Sebelas Maret, hlm. 3.
} 
tanah pun diatur dalam Pepres No. 71/2012, masyarakat pun memiliki peran yang sangat penting dalam pengadaan tanah yang mana masyarakat hukum adat terlibat dalam proses musyawarah untuk mencapai kesepakatan mengenai bentuk kerugian. Namun saat proses tersebut, masyarakat hukum adat seringkali tidak terlibat sehingga masyarakat merasa tidak puas dengan hasil atau kesepakatan ganti kerugian tersebut. Maka dari itu, pengaturan mengenai hak-hak masyarakat hukum adat dalam pengadaan tanah perlu lah diperjelas agar memberikan kepastian hukum serta perlindungan hukum kepada masyarakat hukum adat.

\section{REFERENSI}

\section{Peraturan Perundang-Undangan}

Indonesia, Undang-Undang Dasar Negara Republik Indonesia Tahun 1945.

Undang-Undang Nomor 2 Tahun 2012 tentang Pengadaan Tanah Bagi Kepentingan Umum

Undang-Undang Nomor 5 tahun 1960 tentang Peraturan Dasar Pokok-pokok Agraria.

Peraturan Psresiden Nomor 71 Tahun 2012

\section{Buku}

Fauzie, Ahmad Ridwan. (1982). Hukum Tanah Adat. Dewarucci press: Jakarta.

Harsono, Boedi. (1999). Hukum Agraria Indonesia Sejarah Pembentukan Undang-Undang Pokok Agraria Isi dan Pelaksanaanya Jilid 1. Djamatan.

Kansil, C.S.T. (1989). Pengantar Ilmu Hukum dan Tata Tertib Hukum Indonesia. Balai Pustaka: Jakarta.

Nasucha, Chaizi. (1994). Politik Ekonomi Pertanahan dan Struktur Perpajakan atas Tanah. Jakarta: Kesaint Blanc.

Rusmadi Murad. (2007). Menyingkap Tabir Masalah Pertanahan. Mandar Maju. Bandung.

Setiono. (2004). Rule Of Law (Supermasi Hukum). Surakarta. Magister Ilmu Hukum Program Pascasarjana Universitas Sebelas Maret

Soemitro, Ronny Hanitijo. (1985). Metode Penelitian Hukum. Ghalia Indonesia: Jakarta.

Soekanto, Soerjono. (1996). Pengantar Penelitian Hukum. UI Pres: Jakarta.

Sukanthi, Arie Hutagulung. (2007). Kewenangan Pemerintah di Bidang Pertanahan. PT. Raja Grafindo: Jakarta.

dan Sri Mamudji, 2001, Penelitian Hukum Normatif Suatu Tinjauan Singkat, Rajawali Pers: Jakarta.

Togatorop, Marulak. (2020). Perlindungan Hak Atas Tanah Masyarakat Hukum Adat Dalam Pengadaan Tanah Untuk Kepentingan Umum, Yogyakarta 
Warman, Kurnia. (2010). Hukum Agraria Dalam Masyarakat Majemuk Dinamika Interaksi Hukum Adat dan Hukum Negara di Sumatera Barat. Penerbit HuMa : Jakarta.

\section{Jurnal}

Basri Hasan. (2013). Keadilan dan Kepastian Hukum Bagi Pemegang Hak Atas Tanah Dalam Pengadaan Tanah Untuk Kepentingan Umum. Jurnal IUS, Vol. 1 No.1.

Djanggih, Hardianto. (2017). Aspek Hukum Pengadaan Tanah bagi Pelaksanaan Pembangunan untuk Kepentingan Umum, Jurnal Hukum Pandecta Vol. 12 No. 2.

Doly, Denico. (2011). Keududukan Tanah Ulayat dalam Perancangan Undang-Undang tentang Pengadaan Tanah Untuk Pembangunan Umum. Jurnal Kajian Vol. 16 No. 3.

D., Suyatna, Dkristian, I.N. And Dahana, C.D. Kewenangan Pemerintah Daerah Dalam Pengadaan Tanah Bagi Pelaksanaan Pembangunan Untuk Kepentingan Umum.

Indriasti, Widyarani Wardani. (2013). Pengadaan Tanah Bagi Pembangunan Untuk Kepentingan Umum (Telaah Terhadap Undang-Undang Nomor 2 Tahun 2012 Tentang Pengadaan Tanah Bagi Pembangunan Untuk Kepentingan Umum). Jurnal Hukum dan Dinamika Masyarakat Vo. 10 No.2.

Mumpuni, Retno dkk. (2017). Peran Serta Ondofolo Dalam Ganti Rugi Tanah Untuk Kepentingan Umum Yang Berkeadilan. Jurnal Ilmiah Pendidikan Pancasila dan Kewarganegaraan Vol. 2 No. 1.

Karolina, Ika Octafionita. (2018). Ganti Rugi Pembebasan Tanah Menutur UndangUndang Nomor 2 Tahun 2012 Tentang Pengadaan Tanah Bagi Pembangunan Untuk Kepentingan Umum. Jurnal Lex Privatum Vo. 6 No. 3.

Ramadhani, Rahmat. (2019). Eksistensi Hak Komunal Masyarakat Hukum Adat Dalam Pengadaan Tanah Untuk Kepentingan Umum. Jurnal Penelitian Hukum De Jure Vol. 19 No.1.

Sengkey, Swingly. (2019). Problematika Dalam Pengadaan Tanah Untuk Kepentingan Umum Menurut Undang-Undang Nomor 2 Tahun 2012, Lex Privatium Vol. 7 No. 1.

Sufriadi, Yanto. (2011). Penyebab Sengketa Pengadaan Tanah Untuk Kepentingan Umum (Studi Kasus Sengketa Pengadaan Tanah Untuk Kepentingan Umum di Bengkulu). Jurnal Hukum Vol. 18 No. 1.

Syafirna, Rachma. (2019). Pengaruh Hukum Adat Dalam Proses Peralihan Hak Atas Tanah Ulayat Pada Pembangunan Perluasan Bandara di Jayapura. Otentink's: Jurnal Hukum Kenotariatan Vo. 1 No.1

Tehupeiory, Aartje. (2017). Problematika Pertanahan dan Strategi Penyelesaian Konsinyasi Pengadaan Tanah Untuk Kepentingan Umum. Prosiding Seminar Nasional: Problematika Pertanahan dan Strategi Penyelesaiannya. 
Truzna, Happy Wijaya. (2020). Tinjauan Hukum Pelepasan Tanah Ulayat. Mimbar Keadilan Vol. 13 Nomor 1.

Wulan, Dwi Pujitriyani. (2014). Pengadaan Tanah dan Problem Pemukiman kembali: Skema Pemberdayaan Untuk Perlindungan Masyarakat Terdampak. Jurnal Bhumi No. 40 Tahun 13.

Zakarsih, Hery. (2018). Pelaksanaan Peran Serta Masyarakat Pada Pengadaan Tanah Untuk Kepentingan Umum (Studi Kasus Pelebaran Jalan di Kota Praya, Kabupateen Lombok Tengah). Media Keadilan: Jurnal Ilmu Hukum Vol. 9 No. 2.

\section{Internet}

Yewen. 2019. Ratusan Masyarakat Adat Suku Wally Tuntut Ganti Rugi Hak Ulaya. https://www.jpnn.com/news/ratusan-masyarakat-adat-suku, di akses pada 21 Oktober.

Imbiri, Charles. Tak Dapat Ganti Rugi, Masyarakat Palang Jalan Trans Papua Manokwari. https://www.mcwnews.com/read/2019/02/23/3279/tak-dapat-gantirugi-masyarakat-palang-jalan-trans-papua-manokwari-sorong.html. diakses pada 22 Januari 2021. 